\title{
The effects of international acquisitions in Serbia on status and engagement of human resources
}

\author{
Article history: \\ Received 16 January 2013 \\ Sent for revision 29 March 2013 \\ Received in revised form 15 April 2013 \\ Accepted 15 April 2013 \\ Available online 15 April 2013
}

\begin{abstract}
In the past few decades globalization and deregulation of international economy has been noticeably accelerated. Consequently, new globalized business environment with numerous business opportunities as well as growing business risks has been made. The new business environment opened the door to intensive implementation of acquisitions as a market entry strategy. Foreign direct investments (FDI) in most of transition countries, including Serbia, predominantly come in the form of international acquisitions. There is a wide theoretical analysis of the effects of FDIs on target country economy. The overall conclusion is that green field projects, in comparison with international acquisitions, exert more favorable effects on all aspects of host country's economy. This paper examines the effects of international acquisitions in Serbia on work practices, wages and productivity using the analysis of the financial statements and the results of survey carried out among the foreign investors. It was found that decline of employment; productivity growth and increase in real wages are the results of the acquisitions. The survey also shows that the foreign investors invested in training and development of the acquired employees.
\end{abstract}

Key words: Human resources, international acquisitions, productivity and real wages, Serbia

Rezime: Poslednjih decenija primetan je ubrzani trend globalizacije i liberalizacije međunarodnih ekonomskih odnosa. Posledica ovih procesa je izmenjeni globalni poslovni ambijent koji se odlikuje novim poslovnim prilikama ali $i$

\footnotetext{
${ }^{1}$ Prof. dr Rakita Branko, Faculty of Economics, Belgrade, e-mail: brakita@sbb.rs

${ }^{2}$ Dr Marković Dušan, Faculty of Economics, Belgrade, e-mail: dusanm@ekof.bg.ac.rs 
Rakita, Marković: The effects of international acquisitions in Serbia on...

rastućim rizicima poslovanja. Novi poslovni ambijent stvorio je pretpostavke da kompanije intenzivno primenjuju preuzimanja kao vid strategije ulaska na inostrana tržišta. Kod većine tranzicionih zemalja, kao i u Srbiji, međunarodna preuzimanja čine dominantan oblik stranih direktnih investicija (SDI). U teoriji je široko analiziran uticaj SDI na ekonomiju zemlje domaćina. Preovladao je stav da su pozitivni uticaji na sve aspekte ekonomije zemlje domaćina mnogo značajniji kod green field projekata nego kod međunarodnih preuzimanja. $U$ radu će se na bazi analize finansijskih izveštaja $i$ anketiranjem stranih investitora ispitivati efekti međunarodnih preuzimanja u Srbiji na položaj ljudskih resursa, njihove realne zarade i produktivnost. Utvrđeno je da jednu od posledica međunarodnih preuzimanja u Srbiji predstavlja pad zaposlenosti, rast produktivnosti i rast realnih zarada. Takođe na bazi rezultata anketiranja biće pokazano da su strani investitori investirali u obuku i unapređenje sposobnosti preuzetih kadrova.

Ključne reči: Ljudski resursi, međunarodne akvizicije, produktivnost i realne zarade, Srbija

\section{Introduction}

Between 1917 and 1950 countries that comprised around one third of the world population abandoned market economy and adopted centrally planned economic system (World Bank, 1996). The succeeding years brought similar change in economic policy, with certain degree of variation, in few more countries so centrally planned economies existed in Europe, Asia, Africa, Central and South America. However, the system based on autarchy eventually reached its peak, becoming more and more inefficient. The cause of inefficiency laid in insufficient information that only market could provide, and corrupt practices during the planning.

Because centrally planned economies eventually became unsustainable, most of these countries began the process of transition to market economies at the end of 1980s and the beginning of 1990s. Transition includes foreign investment deregulation, too. Due to deregulation and mass privatization of state-owned enterprises, many transition economies marked a significant inflow of foreign capital. Since domestic capital accumulation is limited, FDIs are a significant source of finance for projects and the factor of reindustrialization. Effects of FDIs on transition economies are multidimensional, and they have been analyzed from different aspects in economic theory.

The first part of this paper gives the analysis of the influence FDls have on competitive potential of transition countries. Relevant results of the study into the relationship between FDIs and various aspects of competitiveness of transition economies are presented. Previous research has shown that FDIs can 
affect degree of competition, balance of payments, larger inflow of foreign capital, technology basis and labor force (Ranđelović, Gligorić, \& Marković, 2009).

Great deal of stress is put on specific effects of international acquisitions. The overall conclusion is that if the process of attracting FDIs is properly managed, their net effect on host country is positive, even if FDls predominantly come in the form of international acquisitions.

The influence of international acquisitions on employment, labor force productivity and real wages is then studied using the analysis of financial statements of relevant middle-size and large international acquisitions in Serbia. Many theoretical and empirical studies indicate negative impact of cross-border acquisitions on employment. However, a recent research shows that crossborder acquisitions lead to decrease in number of production workers rather than administration officers (Lehto \& Bockerman, 2008). This can be partially due to transfer of capital intensive technology from investor to target. Research into cross-border acquisitions conducted in Sweden shows that acquisitions increase productivity in targeted firms but that the first effects are produced one to five years after the acquisition is made (Karpaty, 2007). It is also noticed that productivity gains made through vertical acquisitions are much bigger than through horizontal ones (Bandick, 2011). Previous empirical studies found that real wages of skilled and less skilled workers increase after acquisitions (Bandick, 2011), though not immediately after acquisition is made but one to three years later (Huttunen, 2007).

The third chapter offers an insight into foreign investors' management activities directed at training and development of the acquired employees' using interviews with and surveys taken among the managers. Investments in employee training and development, engagement of expatriate managers and development of young employees are analyzed separately. A special need exists in targets in transition countries to invest in employee training and hire expatriate managers because acquired stuff lacks the competencies required in market economy (Obloy, 1998).

The hypotheses tested in this paper are:

H1. International acquisitions in Serbia caused decline of employment and increased productivity and real wages in acquired companies.

$\mathrm{H}$ 2. Foreign investors upgraded employee competencies through international acquisitions in Serbia. 
Rakita, Marković: The effects of international acquisitions in Serbia on...

\section{Effects of FDI on Competitive Potential of Transition Countries}

Transition from centrally planned to market economy, is not an end in itself. Its final goal is to increase economic efficiency, productivity and efficient allocation of resources, and advance global economic integration. Though temporary, transition is a duly destabilizing process which causes transitional stagflation, fall in GDP and high inflation rates at its early stages. Productivity increases and prices in open sector rise, and less productive "protected" public sectors take their cue from it and increase wages which triggers inflation at this early stage (Egert, Drine, Lommatzsch, \& Rault, 2002). In economic theory this is known as Balassa-Samuelsson effect. Table 1 shows the effects of stagflation in some transition countries.

Table 1 - Transitional stagflation (World Bank, 2000) and (EBRD, 2011)

\begin{tabular}{|l|c|c|c|}
\hline & $\begin{array}{c}\text { Number of successive } \\
\text { years GDP decrease }\end{array}$ & $\begin{array}{c}\text { Cumulative GDP } \\
\text { decrease in } \%\end{array}$ & $\begin{array}{c}\text { GDP Index } \\
2011 / 1989\end{array}$ \\
\hline Albania & 3 & 33,00 & 180 \\
\hline Bulgaria & 4 & 16,00 & 110 \\
\hline Croatia & 4 & 36,00 & 105 \\
\hline Poland & 2 & 6,00 & 194 \\
\hline Slovenia & 3 & 14,00 & 148 \\
\hline Hungary & 4 & 15,00 & 127 \\
\hline Russia & 7 & 40,00 & 108 \\
\hline Ukraine & 10 & 59,00 & 65 \\
\hline GDP decrease during "Great depression" & & \\
\hline France & 3 & 11,00 & \\
\hline Germany & 3 & 16,00 & \\
\hline Great Britain & 2 & 6,00 & \\
\hline USA & 4 & 27,00 & \\
\hline
\end{tabular}

The data presented in Table 1 shows that duration of stagflation and its consequences vary from country to country. Duration of stagflation and the effects it exerts depend on the state an economy was in before transition and how the process is carried out. Some transition economies faced an extreme fall in GDP which exceeds the effects of The Great Depression that occurred 
at the beginning of the $20^{\text {th }}$ century. In order to stop transitional stagflation it is crucial to use macroeconomic stabilization measures, build up new and develop existing institutions. Proper management of these processes creates the conditions for intensified reindustrialization; i. e. steepens the transition curve. Due to lack of domestic capital accumulation, reindustrialization of transition countries often depends on relevant foreign investments.

Effects of FDI on host country economy, especially in transition countries, are multidimensional, which makes the analysis even more complicated. Host country governments are usually concerned about the following (Rakita, 2006): what are the possible FDI effects on country's sovereignty and independence; in what ways do they influence market transparency and market control; and how do they affect country's balance of payment and development. In the preceding decades the prevailing opinion was that there had been a great conflict between the interests of host country and foreign investors. It was believed that foreign capital and foreign ownership can be a threat to national sovereignty and independence. Nowadays, most countries have a positive attitude towards foreign capital and investments. The country of origin of capital is completely irrelevant. Instead of asking - Whose it is and where does the capital come from? the question - What is the output of certain capital and who benefits from it? is heard more often.

The prevailing opinion in economic theory is that FDI inflow, especially in developing countries, has positive net effects in spite of some negative effects. Business environment where positive effects of FDI inflow dominate potentially negative effects is a goal every transition country should work towards. This gains in importance if one takes into account the empirical research which proved that in fast-growing economies, which comprise transition economies, $1 \%$ increase in the share of FDI in GDP is associated with $0.8 \%$ increase in the growth rate of GDP per capita (Bergsman, Broadma, \& Drebentsov, 2000). This paper examines the influence of FDls on: level of competition, balance of payment, investment climate and development, spread of technology and employment rate.

It is in host country's best interest to provide market transparency and free and increased competition. Yet, host country's concerns that FDls could monopolize the market and shut domestic companies out of controlled business flows are justified. By concentrating market power and competitive potentials, multinational enterprises (MNE) could completely beat domestic competitors, minimizing their number. When MNEs gain market monopoly and absolute advantage, they can dictate commercial conditions, increase prices above real prices, influence channels of distribution, which can altogether have very harmful socio-economic consequences. The risk is higher in countries with lower market potential and undeveloped competition, or when foreign investments come in the form of cross-border acquisitions as opposed to greenfield 
Rakita, Marković: The effects of international acquisitions in Serbia on...

investments. These are potential threats, so every host country has the legitimate right to restrict foreign investors' possible attempts to acquire market monopoly through foreign investments.

Due to low exports and deregulated imports, transition countries mark large deficit in the current account of the balance of payment, especially at the early stages of transition. Foreign capital inflow is the source of financing the deficit caused by increased domestic demand. FDls turned out to be much cheaper source of financing than dept capital or portfolio capital, which especially proves to be true in crisis periods (UNCTAD, 2000). At FDIs in the form of Greenfield projects there is a gradual inflow of capital, while international acquisitions represent a single inflow of capital. In practice, after acquiring an enterprise, especially in the process of privatization, foreign investors keep investing in it in order to advance its market competitiveness. The positive effects of foreign capital inflow keep extending. FDIs can also affect capital account of the balance of payment in two different ways. FDls, especially the market oriented ones, are often import intensive which has negative implications for current account of the balance of payment. Deferred negative effects of FDIs on transition economies' balance of payment are repatriation of profits and capital, which gains in importance in crisis periods (Mencinger, 2009). During the global economic crisis when the inflow of FDls falls, foreign affiliates repatriate profits to domestic parent companies and additionally contract capital account of the balance of payment. Profit repatriation is closely related to transfer pricing. Transfer prices are often used by MNEs to transfer capital to "tax havens", tending to optimize tax burden. This problem gains in importance in transition countries because they often lack adequate transfer pricing regulative or capacities for its efficient implementation (Ranđelovic \& Marković, 2009).

Inflow of foreign capital, especially in the form of greenfield investments and often in the form of international acquisitions, raises production capacities. Research has shown that MNEs' investments exceed the inflow of foreign capital because they obtain a part of its capital from host market, and thus create a multiple positive effects (UNCTAD, 2000). Foreign capital can have positive (crowd in) or negative (crowd out) external effects on domestic investments in host country. To crowd in means to stimulate domestic investments complementary to foreign investments, and to draw in additional inflow of foreign investments. To crowd out means to undertake activities towards preventing domestic companies from approaching market and domestic sources of finance. Empirical research has proved that the positive external effects of FDI dominate the negative ones (Mišun \& Tomsk, 2002).

Capacity to create, take over and learn how to use cutting edge technology is essential for national economy's competitive position. Technological improvements alongside with institutional reforms are some of the principal driv- 
ing forces of economic development. Sharp competition in technology intensive industries has shortened product lifecycle of products, which slows down diffusion of new technology and simultaneously accelerates diffusion of the second generation technology (Fageberg \& Verspagen, 2002). MNE subsidiaries in transition countries usually use more advanced technology than does the host country, although, very often this is not the cutting edge technology. Technology transfer, especially at the early stages of transition, depends on the state of infrastructure and available knowledge workers. Foreign companies could transfer technology corresponding to comparative advantage of a host country, for example cheap labor force corresponds to labor intensive technologies, which could cause stagnation or prevent development of new sectors. According to the World Bank's estimations the new sectors, whose development is primarily stimulated by FDI, should generate $40 \%$ of GDP in order to compensate for the effects of "transition shock" (Đuričin, 2005). Indirect effects of FDIs can be observed in terms of technology spillover to host country economic actors. Technology spillover is mediated by demonstration effects, cooperation between local enterprises and MNE subsidiary and mobility of workers (UNCTAD, 2000). Effects of technology spillover depend on the type of industry, MNE's strategy and the level of host country's economic development. MNE's research and development activities are most often centralized, and they rarely delegate part of these activities to subsidiaries in developing countries. This strategy directly causes brain-drain in transition countries. Many knowledge workers, usually after the acquisition, find employment in MNE research and development centers. In spite of some potentially negative effects, empirical research have showed that there is a direct and statistically strong relationship between FDI inflow, as a source of technology innovations, and GDP growth in transition countries (Campos \& Yuko, 2002).

What are the effects of FDI on employment rate and real income in host country is one of the basic questions. Various factors determine the influence of FDI on unemployment rate. The overall conclusion is that greenfield projects increase employment rate because new operational facilities are constructed. Yet, indirect effects can exceed initial positive effects by several times if domestic companies are pushed out. On the other hand, acquisitions, especially during the process of privatization, often imply employment downsizing due to restructuring and shutting down the departments that already exist within MNE system. The research conducted by UNACTAD showed that the number of employees in privatized enterprises decreased in post-acquisition period, although the rate of the decrease was much lower than the decrease in total employment (UNCTAD, 2000). Effects of privatization on unemployment rate should be observed in the context of acquired enterprise. If the company is in deep financial trouble that could lead to bankruptcy, a number of work positions that would be soon canceled are preserved via privatization (Kalman \& 
Rakita, Marković: The effects of international acquisitions in Serbia on...

Hunya, 2000). The effects foreign investments exert on employment should be observed within the context of "crowd-in" and "crowd-out" effects. Seeing that empirical analyses show that "crowd-in" effects are dominant in transition countries (Mišun \& Tomsk, 2002), we can conclude that foreign investments indirectly produce positive impact on employment in host country. Effects of FDI on real income are hard to determine because they to a large extent depend on the type of industry, form of investment and other local factors. The general conclusion that can be found in economic literature is that acquisitions in transition countries have positive effects on wages, although this conclusion is a subject to criticism.

\section{Effects of International Acquisitions on Employment, Real Wages and Labor Force Productivity}

Aforementioned research showed that FDI in transition economies have highly important effects on labor force. By its number and value international acquisitions make up a bigger share of total FDI, especially at the early stages of transition, hence the need for the analysis of their influence on labor force in transition economies.

Effects of international acquisitions on employment, labor force productivity and real wages will be analyzed in this part of the paper. The analysis is based on MNE financial statements. The database on International acquisitions in Serbia is made up of the information collected from Serbian Privatization Agency, SIEPA, the data on the biggest exporters between 2005 and 2011, personal knowledge and the Internet. The database first comprised information on 110 international acquisitions. The data on international acquisitions after 2009 (the period is too short to be analyzed), before 2000 (the period of foreign ownership is too long), acquisition of assets of bankrupt target (cannot be compared over time), acquisitions where foreign company eventually merged with the acquired target, acquisitions of enterprises that eventually filed for bankruptcy (four cases) or privatization contract was terminated (one case) and acquisition of small legal entities (two cases) was then excluded from the database. Representative sample of 78 acquisitions of large and medium-size enterprises with continuity of business operations at least between 2006 and 2011, and in almost all cases longer, was thus obtained. This is a time series analysis, for the period 2003 and between 2006 and $2011 .^{3}$ The conclusions are based on the comparison between the indicators recorded in the year prior to acquisition and at the end of 2011. The im-

\footnotetext{
${ }^{3}$ In 2003 majority companies had domestic ownership or were acquired short before, therefore the financial indicators before or right after the acquisition can be compared with the indicators from 2006 to 2011.
} 
pact of foreign investors on employment varies depending on the moment when acquisition was made and the length of the period over which it was observed. The shortest analyzed period is two years and the longest is 10 years.

Workers unions and host governments are the parties interested in the effects of international acquisitions on employment and real wages. These stakeholders expect foreign investors to upgrade business operations of acquired enterprises and thus increase employment, real wages, and indirectly increase tax income.

High unemployment rate is one of the burning issues in transition economies. In the past few years the unemployment rates have increased due to global economic crisis. Partial solution to this problem lies in FDI inflow. Economic theory gives the advantage to Greenfield projects over cross-border acquisitions, although international acquisitions can sometimes create new jobs. Influence of cross-border acquisitions in Serbia on employment is analyzed through comparison between the number of employees in targets in the year before acquisitions and at the end of $2011 .^{4}$

The data given in Table 2 is a bit worrying. In 49 acquired enterprises, which accounts for nearly $63 \%$ of the representative sample, more than $20 \%$ of the employees were made redundant in post-acquisition period. In 12 enterprises, which accounts for around $15 \%$ of the representative sample, less than $20 \%$ of employees were laid off. In 17 enterprises the number of employees increased in post-acquisition period, which accounts for about $22 \%$ of the sample. Acquired privately owned companies, with optimal number of employees, and enterprises that expanded their business operations after the acquisition make up the biggest proportion of these 17 companies. The total number of new jobs created in post-acquisition period is 1,977 and the total number of layoffs is 23,291 . Net effect of cross-border acquisitions in Serbia on employment is reduction in the number of employees by 21,314 , which is approximately one third of the number of employees in the year before acquisitions were made. This is the consequence of a large number of surplus employees before privatization, and investments in technologies that are not labor intensive. The data showed that cross-border acquisitions significantly contributed to increase in overall unemployment in Serbia. However, one should be very careful and should not jump to such conclusion because it cannot be said how many employees would be laid off if the analyzed companies, primarily state owned ones, were not acquired by foreign investors

\footnotetext{
${ }^{4}$ A more detailed record of the companies included in the research and the number of employees in every individual company sorted by year can be found on author Dusan Marković's web page within the web site of the Faculty of Economics in Belgrade http://www.ekof.bg.ac.rs/nastosb template.php?br nastosb=1205
} 
Rakita, Marković: The effects of international acquisitions in Serbia on...

Table 2 - Analysis of employment before acquisition and in 2011

\begin{tabular}{|l|c|c|c|c|}
\hline & $\begin{array}{c}\text { More than 50\% } \\
\text { increase in } \\
\text { employees }\end{array}$ & $\begin{array}{c}\text { Up to 50\% } \\
\text { increase in } \\
\text { employees }\end{array}$ & $\begin{array}{c}\text { Up to 20\% } \\
\text { decrease in } \\
\text { employees }\end{array}$ & $\begin{array}{c}\text { More than 20\% } \\
\text { decrease in } \\
\text { employees }\end{array}$ \\
\hline $\begin{array}{l}\text { Number of } \\
\text { companies }\end{array}$ & 5 & 12 & 12 & 49 \\
\hline $\begin{array}{l}\text { Percentage of } \\
\text { the sample }\end{array}$ & $6,41 \%$ & $15,38 \%$ & $15,38 \%$ & $62,82 \%$ \\
\hline
\end{tabular}

Increase in real wages occupies workers unions' interest, too. In market economies increase in real wages is directly related to the growth in labor force productivity. Labor force productivity in acquired companies in Serbia was analyzed for the purpose of this research. Sales income per employee before acquisition and sales income per employee at the end of 2011 were compared. ${ }^{5}$ Comparison between labor force productivity in the year before acquisition was made and at the end of 2011 allows an insight as to how foreign investments in technology and new organization and management style affect productivity in targets. Transfer of innovative technology and management know how directly develops competitive potential of target, and economy as a whole. Demonstration effects and stuff turnover allow spillover of these effects to other Serbian companies. Finally, increased productivity of individual companies allows them utilize their capacities more effectively and increases GDP. In order to make the analysis more realistic, sales income was discounted by annual inflation rates to the present value in 2003 . $^{6}$ Table 3 shows the results of the analysis.

Table 3 - Analysis of real sales income per employee before acquisition and in 2011

\begin{tabular}{|l|c|c|c|c|}
\hline & $\begin{array}{l}\text { More than 100\% } \\
\text { increase in real } \\
\text { sales income } \\
\text { per employee }\end{array}$ & $\begin{array}{l}\text { Between 50\% and } \\
100 \% \text { increase in } \\
\text { real sales income } \\
\text { per employee }\end{array}$ & $\begin{array}{l}\text { Up to 50\% } \\
\text { increase in real } \\
\text { sales income } \\
\text { per employee }\end{array}$ & $\begin{array}{l}\text { Decrease of } \\
\text { real sales } \\
\text { income per } \\
\text { employee }\end{array}$ \\
\hline $\begin{array}{l}\text { Number of } \\
\text { companies }\end{array}$ & 35 & 8 & 27 & 8 \\
\hline $\begin{array}{l}\text { Percentage of } \\
\text { the sample }\end{array}$ & $44,87 \%$ & $10,26 \%$ & $34,62 \%$ & $10,26 \%$ \\
\hline
\end{tabular}

\footnotetext{
${ }^{5} \mathrm{~A}$ more detailed record of the companies included in the research and the real sales income per employee for every individual company sorted by year can be found on author Dusan Marković's web page within the web site of the Faculty of Economics in Belgrade http://www.ekof.bg.ac.rs/nastosb template.php?br nastosb=1205 ${ }^{6}$ The inflation rates were taken from the IMF database.
} 
According to the analysis real sales income per employee decreased after the acquisition in only 8 acquired enterprises. In 35 enterprises, which accounts for around $45 \%$ of the sample, there was more than $100 \%$ increase in real sales income per employee. In 8 enterprises the rise in real sales income per employee ranged from $50 \%$ to $100 \%$. Among the enterprises where the rise in real sales income per employee was more than $50 \%$ only 7 had impressive productivity growth that was followed by new hiring. According to the data presented in Table 3, labor force productivity growth in post-acquisition period occurred because sales income growth rate was higher than inflation rate, and in most cases the number of employees was decreased to optimal level. The results are in line with the recent research indicating that cross-border acquisitions help improve the sorting and matching of plants and workers to more efficient use (Siegal \& Simons, 2010).

According to the analysis, labor force productivity increased significantly in post-acquisition period, and a precondition for higher real gross wages was fulfilled. Real gross wages dynamics was analyzed via comparing real gross wages before acquisition and at the end of $2011^{7}$. In order to get reliable analysis, real gross wages were discounted by annual inflation rates to the present value in 2003. In 2009 Serbian Government adopted a set of incentive measures to increase employment, which included tax exemption on RSD 5,000 of total net wage. The effects of this change in tax policy on the results of the analysis are negligible because annual savings on gross labor costs per employee were something more than RSD7,000 in nominal terms or between RSD 3,200 and RSD 3,800 in real terms, depending on the year. Table 4 presents the results of the analysis of real gross labor costs per employee.

Table 4 - Results of the analysis of real gross wages per employee before acquisition and in 2011

\begin{tabular}{|l|c|c|c|c|}
\hline & $\begin{array}{c}\text { More than 100\% } \\
\text { increase in real } \\
\text { gross wages per } \\
\text { employee }\end{array}$ & $\begin{array}{c}\text { Between } 50 \% \text { and } \\
100 \% \text { increase in } \\
\text { real gross wages } \\
\text { per employee }\end{array}$ & $\begin{array}{c}\text { Up to } 50 \% \\
\text { increase in real } \\
\text { gross wages } \\
\text { per employee }\end{array}$ & $\begin{array}{c}\text { Decrease of } \\
\text { real gross } \\
\text { wages per } \\
\text { employee }\end{array}$ \\
\hline $\begin{array}{l}\text { Number of } \\
\text { companies }\end{array}$ & 22 & 13 & 24 & 19 \\
\hline $\begin{array}{l}\text { Percentage of } \\
\text { the sample }\end{array}$ & $28,21 \%$ & $16,67 \%$ & $30,77 \%$ & $24,36 \%$ \\
\hline
\end{tabular}

\footnotetext{
${ }^{7} \mathrm{~A}$ more detailed record of the companies included in the research and real wages in every individual company sorted by year can be found on author Dusan Marković's web page within the web site of the Faculty of Economics in Belgrade http://www.ekof.bg.ac.rs/nastosb template.php?br nastosb=1205
} 
Rakita, Marković: The effects of international acquisitions in Serbia on...

According to this analysis there was a disproportion between productivity growth and real growth in gross wages. In 35 enterprises, which account for $45 \%$ of the sample, real gross wages increased by more than $50 \%$ after the acquisition. However, in 19 companies, or about $24 \%$ of the sample, gross wages were lower than in the year preceding acquisition. It is interesting that in some of these 19 companies growth in productivity rate measured by real sales income per employee was up to $70 \%$. Besides a number of companies in deep financial troubles, this group comprises firms that recorded positive financial results, which indicates that sometimes management tends to achieve successful performance at the expense of employees' wages. Growth in real wages in target firms exerted positive effects on economy as a whole. A basis for boosting domestic savings and consumption were thus created, which will contribute to GDP growth.

Results of the analysis presented in this part of the paper show that international acquisitions had a strong negative net effect on employment. In most analyzed cases decrease in number of employees and labor force productivity growth were directly proportional. The rise in labor force productivity resulted in higher wages. However, productivity growth rate was much higher than real gross wages growth rate, while around $25 \%$ of the enterprises in the sample recorded fall in real gross wages per employee.

\section{Effects of International Acquisitions on Employee Competencies}

Acquisitions in transition countries are fraught with risks and uncertainty due to unstable business environment, and structural problems as a legacy of socialist period. Due to inadequate age and qualification structure of employees, management of human resources is very complex and of crucial importance in the process of acquisition. Most companies in transition economies, even the private owned ones, employ excessively large number of people that exceeds the market needs. Additionally, employee competencies are usually at a very low level. Acquisitions in transition countries usually imply rationalization of employees, human resources training and development and engagement of new employees possessing required skills (Santalainen, Baliga \& Leimman, 2003). Management of human resources should start in preacquisition phase in order for employees to contribute to creation of value.

When writing Due Diligence report the number and structure of employees, and the improvements necessary for labor force to contribute to finding synergy must be determined. Human resources managers play crucial role at this stage. Potential surplus employees must be identified in order to cut costs. Employment reduction is a measure that brings down costs in the short term. 
However, this measure should be used very carefully because it can cause quality employees drain (Krishnana, Hitt, \& Park, 2007). Human resources management should, right after the acquisition, start an open communication with employees to prevent uncertainty and rumor spreading that can cause unexpected drain of employees (Scweiger, Csizar, \& Napier, 2002). The goal of the analysis of human resources at pre-acquisition stage is not just the rationalization of employees. It sets the base for further development of human capital.

At friendly acquisitions, and with afore established relationship with the target, human resources training and development should start even before the target is formally acquired. This spears time, due to overlapping phases, and simultaneously makes it clear to employees that a new business practice takes place after the acquisition (Obloy \& Thomas, 1998). It is crucial to identify the employees with the potential to meet the new standards. This primarily refers to management which tended to meet technical standards in socialist system, neglecting its marketing functions. Taking into account the specific institutional and cultural environment and the fact that the employees usually lack tacit knowledge, mere imitation of training and development strategies applied in developed countries will not produce desirable effects. In order for training and development strategy to increase efficiency and effectiveness of employees, the peculiarities of the new environment must be recognized. There are three levels of knowledge upgrading: 1. technical level 2. systemic level 3. strategic level (Meyer, 2002).

Acquisitions in transition economies often imply intensive investments in new technologies with the aim of upgrading the technology baseline. However, employees lack experience with new technologies, hence the need for technical knowledge upgrading. This type of training is the most simple since it usually refers to the transfer of explicit knowledge. Technical knowledge upgrading training comprises production workers, nonproduction workers and management. Systemic knowledge upgrading refers to acquisition of new procedures and requires integrative learning and coordination between business functions and processes. This level usually includes management, but can comprise some production and nonproduction workers, too. This is the combination of explicit and tacit knowledge, and the transfer of knowledge is much more complex than on technical level. Finally, at the strategic level managers change their cognitive framework for doing business and conducting management tasks (Meyer, 2002). Managers must understand technological and managerial processes, and develop entrepreneurial skills and willingness to take risk. This kind of knowledge is highly tacit, so the process of transferring it is time intensive and apart from the formal trainings it includes learning through practice. 
In spite of implementation of training and development strategies, acquired employees often fail to meet business requirements. Although transition countries possess large labor force, they lack workers with specific competencies (Sheksnia, 1998). Foreign investors therefore have to engage employees from the outside. This often implies high costs and sometimes, especially when foreign investor is a late follower, it is impossible to find such employees in local market. Consequently, companies engage expatriate managers and work intensively on recruitment and training and development of young employees. Engagement of expatriate managers implies high costs and various risks so it should be carefully considered. The aim of hiring expatriate managers is the transfer of business practices from the central to acquired targets. They are also expected to contribute to the strategic knowledge upgrading. Expatriate managers should be familiar with institutional differences between investors' home country and the host country and possess cross-cultural competencies to prevent cultural disharmony or misunderstanding and thus successfully fulfill these tasks. Finally, long term oriented companies create a base for recruitment and training and development of young employees through cooperation with educational institutions. Engagement of young people who received quality formal education abroad and decided to return to their home country, educated repatriates, is a very useful strategy because these employees are familiar with cultural and institutional context in both investor's home country and its target country (Rakita, 2006). This strategy can prevent aforementioned cultural misunderstandings and more successfully upgrade business knowledge than expatriate workers.

The analysis of the effects international acquisitions in Serbia exerted on labor force competencies is based on theoretical research and the sample of 110 relevant acquisitions. The data on international acquisitions after 2010 (the period is too short to be analyzed), before 2000 (the period of foreign ownership is too long), acquisitions of enterprises that eventually filed for bankruptcy (four cases) or privatization contract was terminated (one case) and acquisition of small legal entities (two cases) was excluded from the database in order to get reliable analysis. A sample of 95 relevant acquisitions in Serbia was thus created. Transfer of international business practices from the central to acquired companies was analyzed through a short survey.

At the first stage of the research, communication with a number of companies was established through the network of personal contacts and they agreed to fill out the questionnaire. At the following stage, the questionnaire, the cover letter and an empty envelope with the address of the surveyor printed on it were posted to the remaining companies. The total number of companies that agreed to participate in the survey was 44 , which accounts for $46 \%$ of the sample. The questionnaire employs five-point Likert scale, and the respond- 
ents evaluated three statement. ${ }^{8}$ Foreign investors evaluated the level of employees' competencies and the measures taken to upgrade the efficiency of human resources. Fig. 1 depicts the results of the evaluation of statement: "Acquired human resources did not possess required competencies; therefore we invested in training and development of employees".

Figure 1 - Evaluation of the competencies of acquired human resources

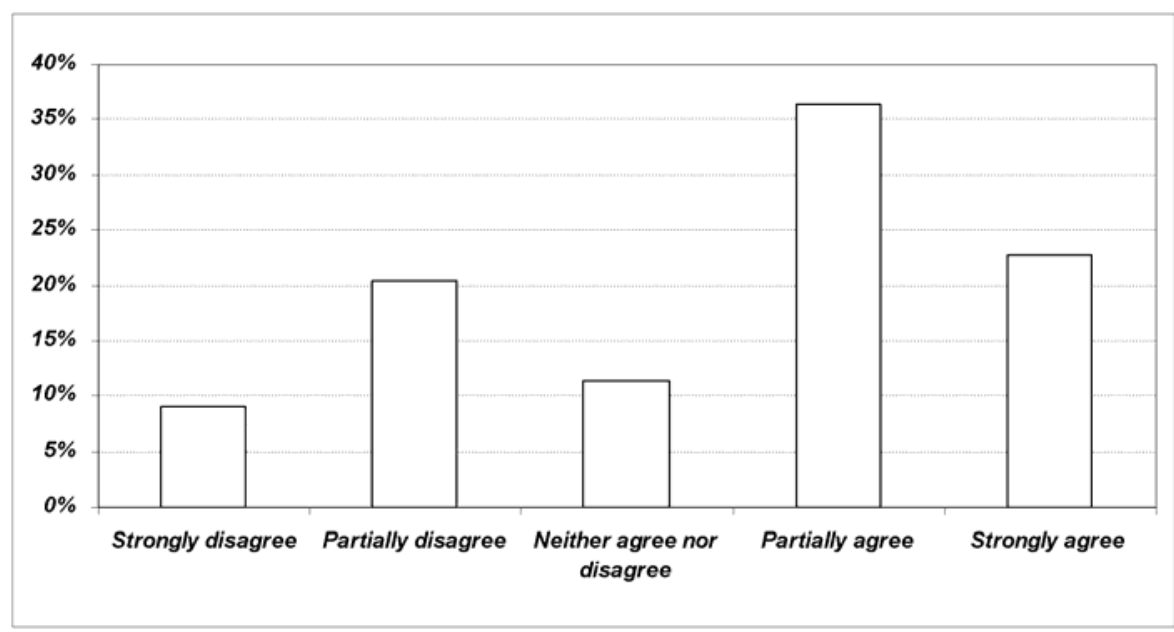

The data presented in Fig. 1 shows that $59 \%$ of foreign investors absolutely or partially agree with the statement. Only $29 \%$ of respondents absolutely of partially disagree with the statement, stating that the acquired human resources did possess the necessary competencies. This scale of responses supports the aforementioned statement that foreign investors most often invest in employee training and development in order to increase labor force productivity. The results are in line with the research showing that a massive knowledge transfer from investor to target takes place after cross-border acquisition is made, while in the later stage mutual knowledge spillovers occur (Bresman, Birkinshaw, \& Nobel, 2010).

Foreign investments in training of employees bring great benefits to Serbian economy. Enhancement of employee competencies allows transfer of new technology to targets, and staff turnover allows spillover of positive effects to whole economy. Increasing level of employee competencies allows further expansion of target's capacities through new production programs. Acquisi${ }^{8} 5$ - strongly agree 4 - partially agree 3 - neither agree nor disagree 2 - partially
disagree 1 - strongly disagree 
Rakita, Marković: The effects of international acquisitions in Serbia on...

tion of new employee competencies helps improve business performance of targets, which contributes to GDP growth.

Foreign investors then evaluated the engagement of expatriate managers as a means of transferring knowledge from the central to local management. Fig. 2 depicts the results of evaluation of the statement: "Acquired management lacked adequate competencies and we had to engage expatriate managers to upgrade transfer of managerial competencies."

Figure 2 - Evaluation of the statement on engagement of expatriate managers

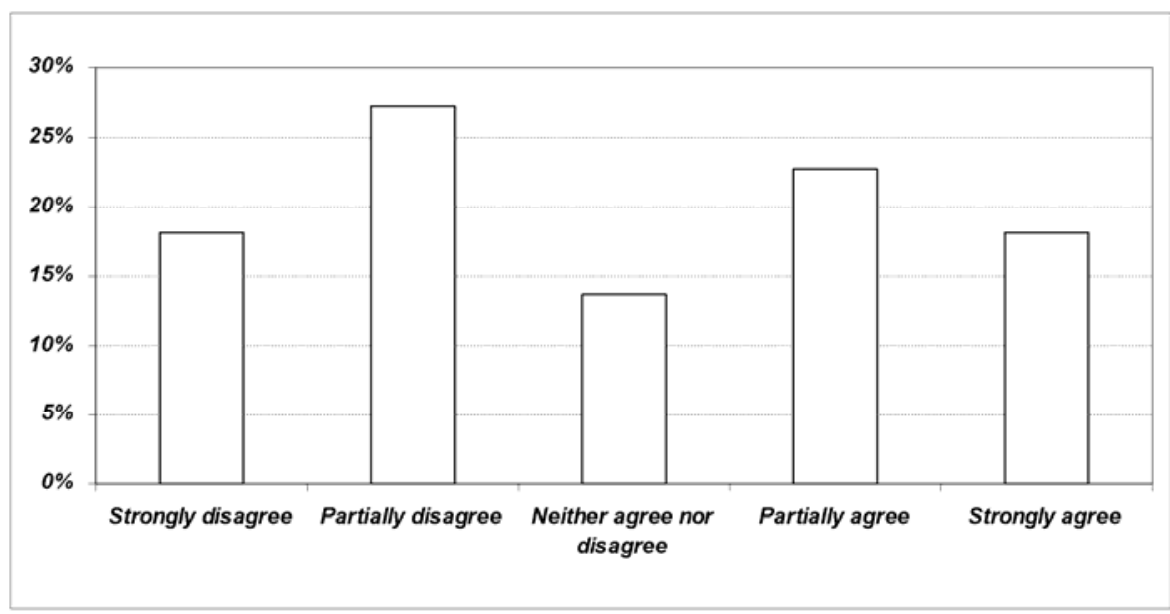

This survey shows that the opinions on engagement of expatriate managers are polarized. Approximately $41 \%$ of respondents absolutely or partially agree with the statement, and $44 \%$ of respondents expressed disagreement with the statement. These results are in accordance with theoretical explanations that engagement of expatriate managers is a highly efficient means of transfer of managerial knowledge from the central to acquired targets, but that it also implies great risks and high costs. Most of the respondents that expressed disagreement with the statement concurred with the aforementioned theoretical explanation and minority of them gives advantage to engagement of local managers because they possess local knowledge. Engagement of expatriate managers will exert positive effects on local management competencies. Local management turnover will contribute to know-how spillovers from target to the whole economy and thus increase its competitiveness. Increased local management competencies will exert positive effects on target firm productivity and consequently on overall economic growth.

Finally, foreign investors evaluated the activities towards training and development of young employees. Fig. 3 depicts the results of evaluation of the 
Rakita, Marković: The effects of international acquisitions in Serbia on...

statement: "Various activities towards development of young employees were taken in acquired companies (cooperation with educational institutions, scholarship programs for high school and university students, engagement of educated repatriates ${ }^{9}$...)."

Figure 3 - Evaluation of the statement on young employees

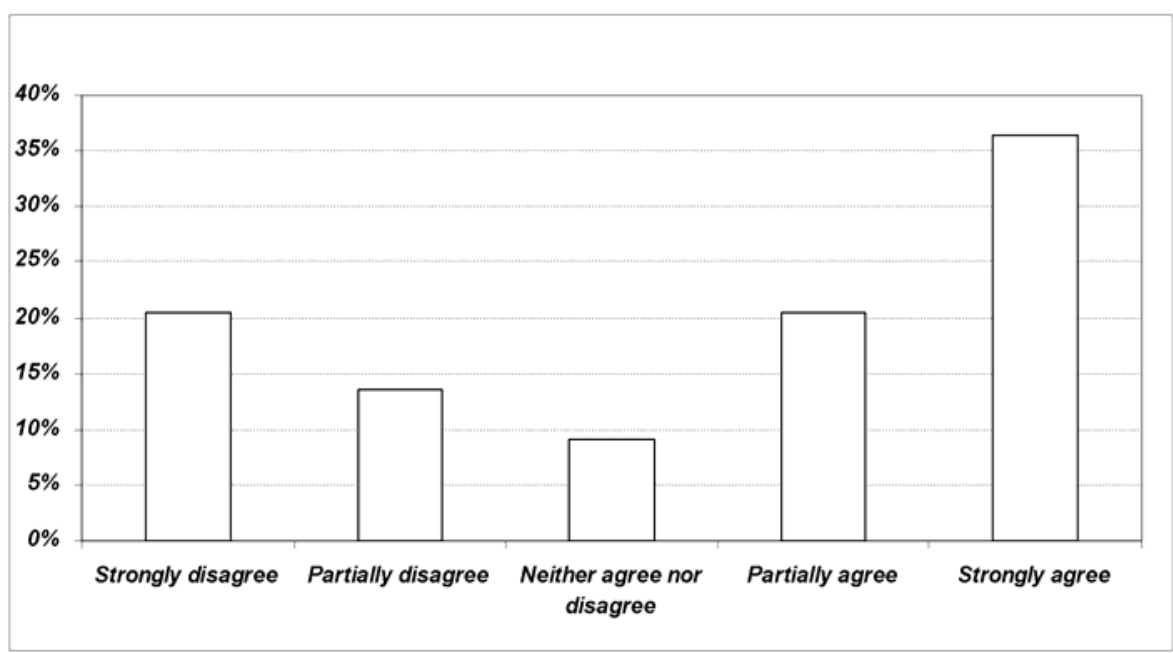

The results of the survey show that foreign investors are strongly determined to invest in development of young employees. Over $56 \%$ of respondents absolutely of partially agree with the statement. $32 \%$ or respondents absolutely or partially disagree with this statement. According to the survey, foreign investors support talented high school and university students in Serbia via different scholarship programs and cooperate with educational institutions, imitating a practice that proved highly efficient in developed countries. Positive effects of investments in young employees will be numerous - brain drain slowdowns, increased competencies of young employees create conditions for enhancement of technology basis in targets, and staff turnover allows spillover of these effects into other companies in Serbia. It is important to point out that through these programs young employees in Serbia apply the knowledge they gained abroad, which could be a basis for increase in competitiveness of Serbian economy.

Results of the survey support aforementioned theoretical assumption. A significant proportion of respondents agreed with the statement that investments in training and development of acquired employees were necessary and that

\footnotetext{
${ }^{9}$ Students from Serbia attending universities in foreign investors' home country, who wish to return to their home country after graduating.
} 
Rakita, Marković: The effects of international acquisitions in Serbia on...

they have taken activities towards recruitment, training and development of young employees.

\section{Conclusions}

Like in all other transition countries, the shift from centrally planned to market economy in Serbia proved to be a highly complex and destabilizing process. Transition implies deregulation of foreign investments and privatization of state owned enterprises, which encourages inflow of FDI. Most economists agree that FDls in general exert positive effects on host economy, especially in the case of small countries. FDIs can upgrade host economy via positive balance of payment, transfer of technology and innovations, investments in production capacities and labor force development. Economists often emphasize that green field projects and cross-border acquisitions, as two forms of FDI, affect host economy in different ways.

Cross-border acquisitions make up a significant proportion of total FDI in some transition countries, including Serbia, hence the need for the analysis of their influence on host economy. In economic theory there is a difference of opinion as to the effects of international acquisitions on labor force. This paper identifies the effects of cross-border acquisitions in Serbia on relevant aspects of working conditions and employee engagement (such as employment, real gross wages, labor force productivity and employee competencies) via analysis of financial statements of acquired companies and the survey carried out among foreign investors.

Analysis of the financial statements shows that only 17 acquired companies, or $22 \%$ of the sample, recorded growth in employment comparing to preacquisition period, and $63 \%$ of companies in the sample marked more than $20 \%$ fall in the number of employees. The net effect cross-border acquisitions in the sample exerted on employment at the end of 2011 was 21,314 lay-offs. Optimized labor force and income sales growth caused rise in real sales income per employee in $90 \%$ of the companies in the sample at the end of 2011 compared with pre-acquisition period. The growth in real sales income per employee was followed by rise in real gross wages, though not to the same proportion. $76 \%$ of companies in the sample paid higher real gross wages at the end of 2011 compared to pre-acquisition period. This leads to conclusion that the analysis proves the hypothesis $\mathrm{H} 1$ - International acquisitions in Serbia caused decline of employment and increased productivity and real wages in acquired companies.

The survey carried out among foreign investors in Serbia shows that more than $60 \%$ of respondents think that acquired human resources lacked required competencies and that the investments in training and development of 
employees were necessary. More than $40 \%$ of companies that participated in the survey engaged expatriate managers after acquisition with the aim of upgrading managerial competencies of local managers. $56 \%$ of respondents agreed with the statement that development of young employees via scholarship programs, cooperation with educational institutions, and engagement of educated repatriates etc. is among company's top priorities.

Empirical research mediated by the survey proves the hypothesis $\mathrm{H} 2$ - Foreign investors increased employee competencies through international acquisitions.

According to this research, cross-border acquisitions in Serbia significantly decreased employment rate. This is due to a large number of surplus employees before acquisition, especially in public owned companies, the global financial crisis and implementation of technology that is not labor intensive. Optimized number of employees and investments in acquired companies brought about strong productivity growth, measured by real sales income per employee. The productivity growth set the basis for rise in real gross income. However, real gross income growth rate was lower than productivity growth rate. Finally, the survey shows that the foreign investors put training and development of acquired employees on the list of business priorities, which contributed to international competitiveness of enterprises from Serbia.

\section{References}

Bandick, R. (2011). Foreign Acquisitions, Wages and Productivity. The World Economy, 34(1), 931-951. doi: 10.1111/j.1467-9701.2011.01345.x

Bergsman, J., Broadma, G.H., \& Drebentsov, V. (2000). Improving Russia's Policy on Foreign Direct Investment. World Bank. Working Paper 2329. Retrieved from http://elibrary.worldbank.org/content/workingpaper/10.1596/1813-9450-2329

Bresman, H., Birkinshaw, J. \& Nobel, R. (2010). Knowledge transfer in International Acquisitions. Journal of International Business Studies. 41(1), 5-20. doi:10.1057/jibs.2009.71

Campos, F.N., \& Yuko, K. (2002). Foreign Direct Investment as Technology Transferred: Some Panel Evidence from the Transition Economies. University of Michigan Business School: William Davidson Institute. Working Paper 438. Retrieved from http://papers.ssrn.com/sol3/papers.cfm?abstract_id=307094

Đuričin, D. (2005). Strategija konkurentnosti Srbije 2005-2010. (pp. 10-33). Kopaonik: SES.

EBRD. (2011). Transition Report 2011. London: EBRD.

Egert, B., Drine, I., Lommatzsch, K., \& Rault, C. (2002). The Ballas Samuelson effect in Central and Eastern Europe: Myth or Reality. University of Michigan Business School: William Davidson Institute. Working Paper 483. Retrieved from http://papers.ssrn.com/sol3/papers.cfm?abstract_id=320884 
Rakita, Marković: The effects of international acquisitions in Serbia on...

Fagerberg, J., \& Verspagen, B. (2002). Technology-Gaps, Innovation-Diffusion and Transformation: An Evolutionary Interpretation. Research Policy, 31(8/9), 12911304. http://dx.doi.org/10.1016/S0048-7333(02)00064-1

Huttunen, K. (2007). The Effects of Foreign Acquisitions on Employment and Wages: Evidence from Finnish Establishments. The Review of Economics and Statistics, 89(3), 497-509. doi: 10.1162/rest.89.3.497

Kalman, K., \& Hunya, G. (2000). Privatization and FDI in Central and Eastern Europe. Transnational Corporations, 9(1), 39-67. Retrieved from http://unctad.org/en/Docs/iteiit21v9n1 en.pdf

Karpaty, P. (2007). Productivity Effects of Foreign Acquisitions in Swedish Manufacturing: The FDI Productivity Issue Revisited. International Journal of the Economics of Business, 14(2), 241 - 260. doi: 10.1080/13571510701344038.

Krishnan, H.A., Hitt, M.A., \& Park, D. (2007). Acquisition Premiums, Subsequent Workforce Reductions and Post-Acquisition Performance. Journal of Management Studies, 44(5), 709-732. doi:10.1111/j.1467-6486.2006.00672.x

Lehto, E. \& Bockerman, P. (2008). Analyzing the Employment Effects of Mergers and Acquisitions. Journal of Economic Behavior \& Organization, 68(1), 112-124. Retrieved from http://www.sciencedirect.com/science/article/pii/S0167268108000516

Mencinger, J. (2009). The "Addiction" with FDI and Current Account Balance. In Inostrani kapital kao faktor razvoja zemalja u tranziciji (pp. 3-15). Kragujevac, Serbia: Ekonomski Fakultet

Meyer, K.E. (2002). Management challenges in privatization acquisitions in transition economies. Journal of World Business, 37(4), 266-276. doi:10.1016/S10909516(02)00093-7

Mišun, J., \& Tomšk, V. (2002). Does FDI Crowd in or Crowd out Domestic Investment. Eastern European Economics, 40(2), 38-56. Retrieved from http://www.jstor.org/discover/10.2307/4380291?uid=3738928\&uid=2129\&uid=2\&ui $\mathrm{d}=70 \&$ uid $=4 \&$ sid $=21102120095407$

Obloy, K., \& Thomas, H. (1998). Transforming Former State Owned Companies into Market Competitors in Poland: The ABB Experience. European Management Journal, 6(4), 390-399. doi: 10.1016/S0263-2373(98)00016-4

Rakita, B. (2006). Međunarodni biznis i menadžment. Beograd: Ekonomski fakultet.

Ranđelović, S., \& Marković, D. (2009). Role of Transfer Pricing in Contemporary Business. In Proceeding International Symposium Economy and Business (pp. 118129). Sunny Beach, Bulgaria: International Scientific Publications

Ranđelović, S., Gligorić, M. \& Marković, D. (2009). Determinants of Foreign Direct Investment - Experience of Serbia. In A. Prašćević, B. Cerović \& M. Jakšić (Eds.) Economic Policy and Global Recession (pp. 377-389). Belgrade, Serbia: Faculty of Economics

Santalainen, T., Baliga, R.B. \& Leimman, J. (2003). Straddling for Market Space: Transforming Estonian State Owned Enterprises toward a Free Market Orientation. International Business \& Economics Research Journal, 2(9), 75-89. Retrieved from http://journals.cluteonline.com/index.php/IBER/article/view/3842

Scweiger, D., Csizar, E., \& Napier, N. (1993). Implementing International Mergers and Acquisitions. Human Resources Planning, 16(1), 53-70. Retrieved from http://karhen.home.xs4all.nl/Papers/M\&A/Schweiger\%20et\%20al\%201993.pdf

Siegel, S.D. \& Simons, L.K. (2010). Assessing the Effects of Mergers and Acquisitions on Firm Performance, Plant productivity, and Workers: New Evidence from 
Rakita, Marković: The effects of international acquisitions in Serbia on...

Matched Employer - Employee Data. Strategic Management Journal, 31(8), 903916. doi: $10.1002 / \mathrm{smj} .843$

Shekshnia, S. (1998). Western multinationals' human resource practices in Russia. European Management Journal,16(4), 460-465. doi:10.1016/S02632373(98)00022-X

UNCTAD. (2000). World Investment Report 2000 - Cross border Merger and Acquisitions and Development. Washington: UNCTAD.

World, B. (1996). From Plan to Market. Washington: World Bank.

World Bank. (2000). Transition the First Ten Years. Washington: World Bank. 